\title{
Analysis on Poverty Reduction Effects and Its' Influencing Factors of Farmer Cooperatives in Contiguous and Extremely Poor Areas Based on the Investigation of Qinling-Bashan Mountainous Regions in Sichuan Province
}

\author{
Guoqiang Liu ${ }^{1, \mathrm{a}}$, Bizhong Zhang ${ }^{1, \mathrm{~b}}$, Xinhong $\mathrm{Fu}^{1, \mathrm{c} *}$, Ruixin Zhang ${ }^{1, \mathrm{~d}}$ \\ ${ }^{1}$ College of Management, Sichuan Agricultural University, Chengdu, China
}

\begin{abstract}
Based on the perspective of income increase of farmer cooperatives' members, this paper uses the micro investigation data of 33 cooperatives and 394 members in Qinling-Bashan Mountainous Regions in Sichuan Province, to examine the poverty reduction effects of cooperatives and empirically analyze the factors influencing the poverty reduction effects of cooperatives by the orderly probit model. The results show that the income increase of most members is obvious, which is conducive to the in-depth development of local poverty alleviation. Besides, 9 variables play a significant role in promoting the income increase of members, which are health status, education level, number of labor, proportion of agricultural income, income satisfaction, cooperatives with county demonstration level, "Three Products and One Standard" certification, profit returned by stock/volume, member's right to speak. Compared with Guangyuan, the income increase of members in Bazhong is more significant. However, the poor families and the distance from the market significantly inhibit the income increase of members, which means the cooperatives also face the challenges in poverty reduction. Finally, this paper puts forward policy suggestions for promoting the poverty reduction of cooperatives in Qinling-Bashan Mountainous Regions in Sichuan Province, such as cultivating and expanding cooperatives, strengthening the capacity of cooperatives to reduce poverty and improving the poverty reduction environment of cooperatives.
\end{abstract}

\section{Introduction}

Farmer cooperatives (hereinafter referred to as "cooperatives") have always been regarded as an ideal vehicle for the poor to achieve poverty alleviation through self-help and mutual assistance( $\mathrm{Wu}$ and $\mathrm{Xu}$ 2009 ), and are the most efficient economic organization for Anti-poverty in rural areas(Bo and Li 2017). The policy documents such as the Outline of China's Rural Poverty Alleviation and Development (2011-2020), the Decision of the Central Committee of the Communist Party of China and the State Council on Winning the Fight against Poverty, and other policy documents are the glorious missions given to cooperatives in poverty alleviation from the legal level. According to data from the Ministry of Agriculture and Rural Affairs, as of the end of October 2019, there were 2.203 million registered cooperatives accordance with the law in China, with an average of 3 cooperatives in each administrative village, that is basically every poor village had a cooperative, and farmers joining a cooperative accounted for $48.7 \%$ of the total number of farmers in the country, which means that cooperatives have become one of the most important poverty alleviation vehicles. Therefore, it is of great practical significance to scientifically evaluate the poverty reduction effect of cooperatives and analyze its influencing factors in-depth under the background of the era when the whole society is determined to build a welloff society.

\section{LITERATURE REVIEW}

The poverty reduction mechanism of cooperatives is a hot spot for scholars. Zhang and Gao(2017) thought that the New Agricultural Management Entities, such as cooperatives, shall increase the wage income, property income and transfer income through the innovation of the agricultural business model, and promote the increase of the operating income through the provision of socialized services, so as to lift the poor households out of poverty. Shao and $\mathrm{Yu}(2017)$ further pointed out that cooperatives increased operational income by participating in products such as priority sales, increased wage income by participating in labor such as employment, increased property income by participating in assets such as farmland, and increased transfer income by participating in projects such as project investment. In the context of universal alienation of cooperatives, cooperatives mainly realize poverty reduction function

a1170695746@qq.com, b1456526360@qq.com, c*475994803@qq.com, d476428957@qq.com 
through the comprehensive embodiment of objective poverty reduction mechanism and subjective poverty reduction mechanism. Among them, the former benefits the poor indirectly through promoting the development of agricultural industry in poor areas, increasing employment and activating the value of land resources in the process of pursuing organizational performance, and the latter are cooperatives that take targeted measures to help the poor(Peng 2018). Poor members can get double bonuses of "cooperation and mutual assistance" and “policy support”(Liu 2017).

Poverty reduction effect evaluation is the key to measuring poverty reduction. Sen(2001) thought poverty is increasingly characterizing multidimensional poverty, and anti-poverty measures in the new era are gradually transitioning to multi-dimensional poverty reduction(Wang 2020). However, income poverty reduction is undoubtedly the most important and basic means of poverty reduction, and income poverty reduction effect is also the focus of poverty reduction effect evaluation. For example, China 's current "targeted poverty alleviation" strategy, whose first evaluation index is "one over", that is, the income of poor households must be above the poverty line. Many scholars have examined the income poverty reduction effect of cooperatives, but have not reached a consensus. Some scholars believe that cooperatives are conducive to increasing the income of members, but there are differences between heterogeneous members (Liu 2017; Hu 2014; Zhang 2019). Some scholars hold the opposite view that only a few well-functioning cooperatives has a significant income increase effect (Liao, Ying, Den and $\mathrm{Xu}$ 2016).

The poverty reduction of cooperatives is affected by multiple factors. Cai(2013) found that factors such as gender of household head, education level, planting scale, availability of market information, distance from the market and government support significantly affected the income of members under the "cooperative + peasant household" model. Basic situation, operation activities, management activities and the external environment had a significant positive impact on cooperatives' financial performance, from which the influence of management activity is bigger (Xu, Wu and Ying, 2013). Zhang, Feng and Huang (2012) thought that the impact of cooperatives on farmers' income is closely related to the ratio of wage income to the net income of farmers and the transfer of rural labor. After controlling the individual characteristics and the basic characteristics of cooperatives, the governance mechanism of membership system, equity structure, decision-making mode and earnings distribution had a significant impact on the effect of increasing the income of members(Wang 2016). $\mathrm{He}$ and Liu(2016) pointed out that cooperative factors, member operating factors, and member personal factors have a significant positive impact on members' product net income. Therefore, individual characteristics, family characteristics, cooperative characteristics, and regional characteristics are important dimensions affecting the income poverty reduction effect of cooperatives.

To sum up, Scholars have conducted a lot of discussions on the poverty reduction mechanism, poverty reduction effects and its influencing factors of cooperatives, which have laid the foundation for in-depth analysis of this article, but the disadvantages are as follows: First, Scholars have not reached a consensus on the effects of income poverty reduction of cooperatives, which needs to be further verified. Second, there is a lack of research specifically targeting contiguous and extremely poor areas (Liu 2016), whose are the main battlefields for poverty alleviation. What is the poverty reduction effects of cooperatives? and what factors affecting the poverty reduction effect of cooperatives need to be analyzed in depth. Therefore, based on the perspective of income increase of members, this study uses the micro investigation data of 33 cooperatives and 394 members in Qinling-Bashan Mountainous Regions in Sichuan Province, to examine the poverty reduction effects of cooperatives and empirically analyze the factors influencing the poverty reduction effects of cooperatives by the orderly probit model, which is innovative.

\section{Data sources}

Qinling-Bashan Mountainous Regions in Sichuan Province covers a total of 34 counties (cities and districts) from 6 cities, including Mianyang, Guangyuan, Nanchong, Guang'an, Dazhou and Bazhong, which is an important part of China's contiguous and extremely poor area. As a research area, it is typical to investigate cooperative poverty reduction in contiguous and extremely poor area. Therefore, the research group conducted a survey on the cooperatives and their members in Qinling-Bashan Mountainous Regions in Sichuan Province from July 14, 2016 to July 29, 2016, and the survey mainly adopted the method of stratified random sampling. The specific operations are as follows: Firstly, based on the development status of cooperatives in various regions and their poverty reduction practices, Guangyuan, Guang'an, Nanchong and Bazhong four cities were selected. Secondly, 1-5 poverty-stricken counties (cities and districts) were selected from each sample city. Thirdly, 1-4 cooperatives with good development status was recommended by the staff members in charge of cooperatives in each sample county (city and district), and then questionnaires were conducted on the sample cooperatives and the sample members respectively. In order to improve the quality of survey samples, the sample cooperatives were mainly interviewed by the chairman of the cooperatives or other members of the board of directors, and the sample members' household heads were conducted a questionnaire survey by random sampling. Finally, the obtained sample data is of high quality. Finally, 44 cooperatives were surveyed and 33 valid questionnaires were collected, with an effective rate of $75.00 \% .420$ questionnaires were distributed to members, and 394 valid questionnaires were collected, with an effective rate of $93.81 . \%$. The regional distribution of effective samples of cooperatives and members is shown in table I. 
TABLE I.

REGIONAL DISTRIBUTION OF VALID SAMPLES

\begin{tabular}{|c|c|c|c|c|c|}
\hline \multirow[b]{2}{*}{$\begin{array}{l}\text { Sample } \\
\text { City }\end{array}$} & \multirow{2}{*}{$\begin{array}{l}\text { Sample } \\
\text { County (City, } \\
\text { District) }\end{array}$} & \multicolumn{2}{|l|}{ Members } & \multicolumn{2}{|c|}{ Cooperatives } \\
\hline & & Number & $\begin{array}{l}\text { Proportion } \\
\text { (\%) }\end{array}$ & Number & $\begin{array}{l}\text { Proportion } \\
(\%)\end{array}$ \\
\hline \multirow{5}{*}{$\begin{array}{l}\text { Guangyuan } \\
\text { City }\end{array}$} & Cangxi County & 64 & 16.24 & 3 & 9.09 \\
\hline & Jiange County & 46 & 11.68 & 3 & 9.09 \\
\hline & $\begin{array}{l}\text { Wangcang } \\
\text { County }\end{array}$ & 39 & 9.90 & 3 & 9.09 \\
\hline & $\begin{array}{l}\text { Zhaohua } \\
\text { District }\end{array}$ & 34 & 8.63 & 2 & 6.06 \\
\hline & Total & 183 & 46.45 & 11 & 33.33 \\
\hline \multirow{3}{*}{ Guang'an City } & $\begin{array}{l}\text { Guang'an } \\
\text { District }\end{array}$ & 21 & 5.33 & 4 & 12.12 \\
\hline & Yuechi County & 50 & 12.69 & 4 & 12.12 \\
\hline & Total & 71 & 18.02 & 8 & 24.24 \\
\hline \multirow{3}{*}{$\begin{array}{l}\text { Nanchong } \\
\text { City }\end{array}$} & Nanbu County & 19 & 4.82 & 2 & 6.06 \\
\hline & $\begin{array}{l}\text { Langzhong } \\
\text { City }\end{array}$ & 21 & 5.33 & 2 & 6.06 \\
\hline & Total & 40 & 10.15 & 4 & 12.12 \\
\hline \multirow{6}{*}{$\begin{array}{l}\text { Bazhong } \\
\text { City }\end{array}$} & Enyang District & 30 & 7.61 & 2 & 6.06 \\
\hline & Bazhou District & 7 & 1.78 & 2 & 6.06 \\
\hline & $\begin{array}{l}\text { Nanjiang } \\
\text { County }\end{array}$ & 27 & 6.85 & 2 & 6.06 \\
\hline & $\begin{array}{l}\text { Tongjiang } \\
\text { County }\end{array}$ & 17 & 4.31 & 1 & 3.03 \\
\hline & $\begin{array}{l}\text { Pingchang } \\
\text { County }\end{array}$ & 19 & 4.82 & 3 & 9.09 \\
\hline & Total & 100 & 25.38 & 10 & 30.30 \\
\hline \multicolumn{2}{|l|}{ Total } & 394 & 100.00 & 33 & 100.00 \\
\hline
\end{tabular}

income increase of membership are obtained.

\section{Evaluation of poverty reduction effects of cooperatives}

\subsection{Evaluation method}

This study examines the poverty reduction effects of cooperatives based on the perspective of income increase of members. In view of the fact that directly asking about income involves family privacy, members are more likely to conceal their income, and the conclusions drawn from quantitative analysis based on objective evaluation results may be contrary to reality. However, the adoption of the five-point Likert Scale can effectively make up for this defect (see table II). Among them, the agricultural income after joining the cooperative compared with the previous one is used to measure the income increase effects of members vertically, and the household income compared with the average income level of the whole village is used to examine the income increase performance of members horizontally. According to the research method of Huang, Lin and Xu (2008), the sum of the above two will get the income increase effects of members, which are further subdivided as follows: the sum less than 6 is set as the first level, and the sum equal to 6 is set as the second level, and the sum equal to 7 is set as the third level, ..., the sum equal to 10 is set as the sixth level, from which the six levels of orderly classification variables for the
TABLE II. EVALUATION INDICATORS OF COOPERATIVE POVERTY REDUCTION PERFORMANCE

\begin{tabular}{|l|l|}
\hline Variable & Variable Declaration \\
\hline $\begin{array}{l}\text { the agricultural income } \\
\text { after joining the } \\
\text { cooperative compared } \\
\text { with the previous } \\
\text { one(Y1) }\end{array}$ & $\begin{array}{l}\text { little lower; } 3= \\
\text { Almost; } 4=\text { Higher; } 5= \\
\text { Much higher }\end{array}$ \\
$\begin{array}{l}\text { the household income } \\
\text { compared with the } \\
\text { average income level of } \\
\text { the whole village(Y2) }\end{array}$ & \\
\hline
\end{tabular}

\subsection{Evaluation results}

It can be seen from the foregoing that the level of income increase of the members is derived from the sum of the two five-category variables. The " 3 " in the fivecategory variables is at a medium level. If the average of the sum of the two five-category variables is equal to " 3 ", that is, corresponding to level 2 , the combination is also at a medium level, and the combinations that meet the conditions are $(1,5), \quad(2,4), \quad(3,3), \quad(4,2), \quad(5,1)$. Furthermore, if the level value is greater than 2, it proves that the members' income has increased, that is, the cooperative has a certain poverty reduction effects; if the 
level value is less than 2, it proves that the member's income has decreased, and the cooperative has no poverty reduction effects.

It can be seen that the proportion of members at different levels is $11.42 \%, 17.51 \%, 28.68 \%, 24.62 \%$, $13.96 \%, 3.81 \%$ from table III. Among them, samples from level 2 accounted for $17.51 \%$, indicating that the cooperative had no significant poverty reduction effects. Samples above level 2 accounted for $71.07 \%$, indicating that the income of most members had improved to a certain extent, that is, cooperatives have a positive significance in poverty reduction in Qinling-Bashan Mountainous Regions, Sichuan, which is Conducive to the in-depth development of local poverty alleviation. However, there is significant heterogeneity in the income increase among members, with $10 \%$ of the member samples still below level 2, meaning that the cooperatives not only failed to increase the income of members, but also caused the income of members to decrease. And only $3.81 \%$ of the member samples' income increase was very significant. Therefore, why does the income increase of members show significant heterogeneity? What factors have influenced the income increase of members in Qinling-Bashan Mountainous Regions in Sichuan Province? This will be answered later.

TABLE III. DISTRIBUTION OF THE INCOME INCREASE OF MEMBERS

\begin{tabular}{|c|c|c|c|c|c|c|}
\hline \multirow{2}{*}{$\begin{array}{l}\text { the income increase of } \\
\text { members }\end{array}$} & \multicolumn{6}{|c|}{ Distribution } \\
\hline & 1 & 2 & 3 & 4 & 5 & 6 \\
\hline sample & 45 & 69 & 113 & 97 & 55 & 15 \\
\hline Proportion(\%) & 11.42 & 17.51 & 28.68 & 24.62 & 13.96 & 3.81 \\
\hline
\end{tabular}

\section{Analysis of influencing factors of poverty reduction effects of cooperatives}

\subsection{Research method}

In this study, the dependent variable $(\mathrm{Y}=1,2, \ldots, 6)$ is represented as the ordered classification discrete variables with six levels, and the ordered probit model is the classical method to study this kind of problems, and the income increase of members is approximately obeying the normal distribution (Table III), respectively accounting for $11.42 \%, 17.51 \%, 28.68 \%, 24.62 \%$, $13.96 \%, 3.81 \%$. Therefore, this paper intends to use the orderly probit model to empirical analyze the influencing factors of poverty reduction effects of cooperatives in Qinling-Bashan Mountainous Regions in Sichuan Province. The model is set as follows:

$$
\mathrm{Y}^{*}=\beta_{\mathrm{i}} \mathrm{X}_{\mathrm{i}}+\varepsilon
$$

In the formula (1), $\mathrm{Y}^{*}$ is a latent variable, which indicates the different levels of income increase of the sample members, and $\mathrm{Y}^{*} \in[1,2,3,4,5,6] . \mathrm{X}_{\mathrm{i}}$ is potential factors affecting the income increase of members, which is the actual observed value. $\beta_{\mathrm{i}}$ is the parameter estimation coefficient, $\varepsilon$ is the residual term, and satisfies $\varepsilon \sim \mathrm{N}(0,1)$. Build the selection model as follows:

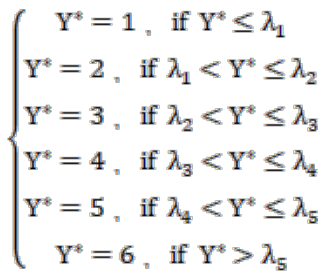

In the formula $(2), \lambda_{j}(j=1,2 、 3,4,5)$ Represents the critical tangent point value, which satisfies $\lambda_{1}<\lambda_{2}<\lambda_{3}<\lambda_{4}<\lambda_{5}$. and then:

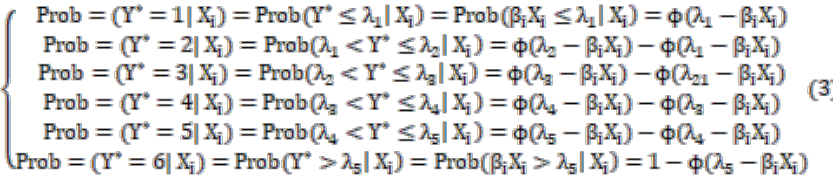

In the formula (3), $\phi$ is the standard normal cumulative distribution function.

\subsection{Variable selection}

Based on relevant research results, this paper analyzes the influencing factors of the income increase of members from four dimensions: members characteristic variables, family characteristic variables, cooperative characteristic variables and regional characteristic variables. The definition and description of each variable are shown in table IV.

TABLE IV. DEFINITION AND DESCRIPTION OF VARIABLES

\begin{tabular}{|l|l|l|l|}
\hline Variable name & Variable Defination & Mean & SE \\
\hline Members characteristic variables & \multicolumn{2}{|l|}{} \\
\hline Health status $\left(x_{1}\right)$ & $\begin{array}{l}\text { 1= very bad; } 2=\text { worse; 3= general; } \\
\text { 4=better; 5= Very good }\end{array}$ & 3.749 & 1.061 \\
\hline Education level $\left(x_{2}\right)$ & actual years of education (years) & 7.114 & 3.345 \\
\hline Special experience $\left(x_{3}\right)$ & $0=$ no; 1=yes & 0.581 & 0.494 \\
\hline $\begin{array}{l}\text { Number of trainings } \\
\text { received }\left(x_{4}\right)\end{array}$ & $\begin{array}{l}1=0 ; 2=1 \sim 2 \text { times; 3=3 4 times; 4=5 6 } \\
\text { times; 5=7 times or more }\end{array}$ & 2.538 & 1.157 \\
\hline
\end{tabular}




\begin{tabular}{|c|c|c|c|}
\hline \multicolumn{4}{|l|}{ Family characteristic variables } \\
\hline Poor family $\left(x_{5}\right)$ & $0=$ no； $1=$ yes & 0.216 & 0.412 \\
\hline Number of labor $\left(x_{6}\right)$ & actual value (number) & 2.863 & 1.253 \\
\hline $\begin{array}{l}\text { Proportion of agricultural } \\
\text { income }\left(x_{7}\right)\end{array}$ & actual value (\%) & 0.319 & 0.333 \\
\hline $\begin{array}{l}\text { Understanding of the } \\
\text { operation and management } \\
\text { of cooperatives }\left(x_{8}\right)\end{array}$ & $\begin{array}{l}1=\text { =ery little; } 2=\text { less; } \\
3=\text { =eneral; } 4=\text { better; } 5=\text { =very well }\end{array}$ & 3.099 & 1.330 \\
\hline \multicolumn{4}{|c|}{ Cooperative characteristic variables } \\
\hline $\operatorname{Income~satisfaction}\left(x_{9}\right)$ & $\begin{array}{l}1=\text { very dissatisfied; } 2=\text { not quite satisfied; } \\
3=\text { general } 4=\text { satisfied; } 5=\text { =very satisfied }\end{array}$ & 3.967 & 0.782 \\
\hline Demonstration level $\left(x_{10}\right)$ & $\begin{array}{l}1=\text { non-demonstration; } 2=\text { county level; } \\
3=\text { city level; } 4=\text { =province level; } 5=\text { national } \\
\text { level, as a dummy variable }\end{array}$ & 3.604 & 1.177 \\
\hline $\begin{array}{l}\text { "Three Products and One } \\
\text { Standard" certification }\left(x_{11}\right)\end{array}$ & $0=$ no； $1=$ yes & 0.604 & 0.490 \\
\hline $\begin{array}{l}\text { Who makes the management } \\
\text { decisions }\left(x_{12}\right)\end{array}$ & $\begin{array}{l}1=\text { the director; } 2=\text { the council; } 3=\text { core } \\
\text { members with more shares; } 4=\text { =member's } \\
\text { congress }\end{array}$ & 2.599 & 1.234 \\
\hline $\begin{array}{l}\text { Has the profit been returned } \\
\text { by stock/volume }\left(x_{13}\right)\end{array}$ & $0=$ no； $1=$ yes & 0.368 & 0.483 \\
\hline Member's right to speak $\left(x_{14}\right)$ & $\begin{array}{l}1=\text { very small; } 2=\text { smaller; } 3=\text { general; } 4= \\
\text { bigger; } 5=\text { very big }\end{array}$ & 2.655 & 1.237 \\
\hline \multicolumn{4}{|l|}{ Regional characteristic variables } \\
\hline $\begin{array}{l}\text { Distance from the market } \\
\left(x_{15}\right)\end{array}$ & distance from market centre $(\mathrm{km})$ & 6.141 & 6.631 \\
\hline $\begin{array}{l}\text { The city where the } \\
\text { cooperative is located }\left(x_{16}\right)\end{array}$ & $\begin{array}{l}1=\text { Guangyuan; } 2=\text { Guang'an } \\
3=\text { Nanchong; } 4=\text { Bazhong, as a dummy } \\
\text { variable }\end{array}$ & 2.145 & 1.251 \\
\hline
\end{tabular}

\subsection{Empirical results and analysis}

In order to ensure the validity of the model estimation, the multicollinearity among the independent variables was tested before the ordered probit regression analysis. The results show that the average value of Variance Inflation Factor (VIF) of each variable is 1.95 , and the maximum value is 4.29 , indicating that there is no significant multicollinearity. Based on this, this paper uses STATA13.0 statistical analysis software to conduct an empirical analysis of the factors affecting the income increase of cooperative members in Qinling-Bashan Mountainous Regions in Sichuan Province, and selects robust robustness estimation to correct possible heteroscedasticity problems. The model estimation results are shown in Table V.

TABLE V. MODEL ESTIMATION RESULTS

\begin{tabular}{|l|l|l|l|}
\hline Variable name & Coefficient & $\begin{array}{l}\text { Standard } \\
\text { error }\end{array}$ & Z- statistics \\
\hline$x_{1}$ & $0.131^{* *}$ & 0.057 & 2.29 \\
\hline$x_{2}$ & $0.055^{* * *}$ & 0.019 & 2.96 \\
\hline$x_{3}$ & -0.024 & 0.114 & -0.21 \\
\hline$x_{4}$ & 0.089 & 0.055 & 1.63 \\
\hline$x_{5}$ & 0.133 & -2.22 \\
\hline$x_{6}$ & $-0.296^{* *}$ & 0.050 & 2.09 \\
\hline$x_{7}$ & $0.105^{* *}$ & 0.184 & 1.96 \\
\hline$x_{8}$ & $0.361^{* *}$ & 0.059 & 1.28 \\
\hline$x_{9}\left(\begin{array}{ll}x^{*} \\
x_{10} \text { Control group: non }\end{array}\right.$ & $0.288^{* * *}$ & 0.082 & 3.50 \\
\hline County & $0.553^{* *}$ & 0.275 & \multicolumn{2}{|l|}{} \\
\hline municipal & 0.009 & 0.234 & 2.01 \\
\hline provincial & -0.115 & 0.211 & 0.04 \\
\hline national & 0.059 & 0.231 & -0.54 \\
\hline$x_{11}$ & $0.220^{*}$ & 0.120 & 0.25 \\
\hline
\end{tabular}




\begin{tabular}{|c|c|c|c|}
\hline$x_{12}$ & 0.030 & 0.053 & 0.57 \\
\hline$x_{13}$ & $0.330^{* *}$ & 0.148 & 2.22 \\
\hline$x_{14}$ & $0.216^{* * *}$ & 0.067 & 3.21 \\
\hline$x_{15}$ & $-0.023^{* *}$ & 0.009 & -2.48 \\
\hline \multicolumn{4}{|c|}{$x_{16}$ (Control group: Guangyuan) } \\
\hline Guang'an & 0.019 & 0.188 & 0.10 \\
\hline Nanchong & 0.106 & 0.223 & 0.47 \\
\hline Bazhong & $0.489^{* * *}$ & 0.149 & 3.29 \\
\hline \multicolumn{4}{|c|}{$\begin{array}{l}\text { Prob }>\text { chi } 2=0.000 \\
\text { Pseudo R2 }=0.139 \\
\text { Log pseudolikelihood }=-561.757\end{array}$} \\
\hline
\end{tabular}

Note: ${ }^{*} \mathrm{p} \leq 0.1 ; * * \mathrm{p} \leq 0.05 ; * * * \mathrm{p} \leq 0.01$.

\subsubsection{The influence of members characteristic variables on the income increase of cooperative members}

The education level passes the significance test at $1 \%$ level, and the influence direction is positive, indicating that the higher the education level of members, the more the income increase of members by cooperatives( $\mathrm{Su}$ and Chen 2014). The education level can increase the human capital of the members, so as to improve their learning ability, acceptance ability and participation ability. However, the education level of the sample members is generally low, and nearly $50 \%$ of the members have the actual education years less than 6 years, and only $15.99 \%$ of the members have the actual education years more than 12 years. Therefore, the low education level is an important disadvantage of the income increase of members.

The health status passes the significance test at $5 \%$ level, and the influence direction was positive, indicating that the better the health status of the members, the more the income increase by cooperatives. Health status is an important index to measure the quality of human capital. The better health status is, the higher the human capital of the members is, the more likely they are to increase their income and get rid of poverty through cooperatives.

The special experience does not pass the significance test at $10 \%$ level, indicating that the special experience has no significant effect on the income increase of members. According to the data, only $58.12 \%$ of the members have special experience, and this proportion is obviously low with free flow of labor force in the current, which is likely to cause the lack of social capital and sluggish income growth of the members.

The training, as a short-term improvement of members' human capital, has not passed the significance test at $10 \%$ level, which is inconsistent with the research conclusion of $\mathrm{Xu}, \mathrm{Wu}$ and Ying(2013). The possible reason is that the applicability and advancement of the training content need to be improved.

\subsubsection{The influence of family characteristic variables on the income increase of cooperative members}

Poor family, number of labor and proportion of agricultural income all pass the significance test at the level of $5 \%$. Among them, the low income family is negative, indicating that the cooperatives have a better effect on improving the non-poor family than poor family, and further illustrating that the phenomenon of "elite capture" exists between the poor and non-poor families in cooperatives, which needs to be taken seriously.

Both the number of labor and the proportion of agricultural income have positive effects, indicating that the larger the number of labor, the higher the proportion of agricultural income, and the higher the income increase of members by cooperatives. The labor force is the main force to create household wealth, and labor resources are optimized between the agricultural and non-agricultural after joining the cooperative. Besides, agricultural productivity is released, and value created is increased, so the income level is naturally increased. The higher the proportion of agricultural income, the more the members focus on agricultural operation, and the more subjective initiative of participating in the cooperative, and the more significant the income increase of members through cooperatives.

Understanding of the operation and management of cooperatives has not passed the significance test at $10 \%$ level, which is inconsistent with the research conclusion of Zhang, Feng and Huang(2012). The possible reason is that the members of the cooperatives in Qinling-Bashan Mountainous Regions in Sichuan Province do not have a strong sense of ownership, and low subjective initiative in daily production, operation, management and other activities, and low participation. Data shows that more than half of the members do not know much about the operation and management of cooperatives.

\subsubsection{The influence of cooperative characteristic variables on the income increase of cooperative members}

Both income satisfaction and member's right to speak 
pass the significance test at $1 \%$ level, and the influence direction was all positive. The income satisfaction of cooperatives depends on the development status of cooperatives. The better the development status of cooperatives, the stronger its market competitiveness and the more significant the effect of driving the income increase of members (Zhang 2016). Therefore, the key to increase the income of members lies in how to develop and expand cooperatives. The member's right to speak is a measure of the internal supervision mechanism of cooperatives. The greater the member's right to speak, the more perfect the supervision system of cooperatives will be, and the more beneficial it will be to protect the interests of members and promote the improvement of their income level, which responds to the research conclusion of $\mathrm{Xu}(2009)$.

Cooperatives at county demonstration level and profits returned by shares/trading volume both pass the significance test at $1 \%$ level, and the impact direction was positive. Among cooperatives with different levels of demonstration, if non-demonstration cooperatives are used as the control group, only cooperatives at county demonstration level significantly promote the income increase of members, and municipal, provincial and national demonstration cooperatives are not through the $10 \%$ level of significance test, which is inconsistent with the research conclusion of Wang(2016), and the possible reason is that there is a misrepresented phenomenon in the construction of demonstration cooperatives, which needs further study. Compared with cooperatives that do not return profits by share/trading volume, cooperatives that return profits by share/trading volume play a more significant role in promoting members' income increase. It can be seen that distribution system plays an important role in the arrangement of cooperative system, and a reasonable and effective distribution method can increase the income level of members(Lou, Chen and Fan 2016).

"Three Products and One Standard" certification has passed the significance test at $10 \%$ level and the impact direction is positive, indicating that compared with the non-certification cooperatives, cooperatives with "Three Products and One Standard" certification have a more significant impact on the income increase of members. As the public pay more and more attention of the food safety problem, especially in background of "Quality Promoting Agriculture, Brand Promoting Agriculture", consumers are keen on high-quality agricultural products, such as agricultural products with "Three Products and One Standard" certification, and their consumption demand is strong. Therefore, cooperatives with "Three Products and One Standard" certification play a more significant role in boosting the income of members, which is one of the key points for cooperatives to promote the income of members.

Who makes the management decisions is failure to pass the significance test at $10 \%$ level, indicating that it will not significantly affect the income increase among members. A possible reason is that the management democracy of cooperatives needs to be further perfect, and the data further show that the management decisions made by the director, the council, core members with more shares and member's congress respectively account for $23.60 \%, 33.25 \%, 2.79 \%$ and 40.36 , and not by member's congress account for $59.64 \%$, which needs more attention.

\subsubsection{The influence of regional characteristic variables on the income increase of cooperative members}

The distance from the market and Bazhong both pass the significance test at $1 \%$ level. Among them, the distance from the market has a negative influence, indicating that the closer the distance from the market center is, the more cooperatives increase the income of members(Cai 2013). The closer cooperatives are to the market center, the more sensitive the members are to the market information of agricultural products, and the easier they are to realize their smallholder status and the organizational advantages of cooperatives. They are more dependent on cooperatives and have stronger subjective initiative. At the same time, the closer cooperatives are to the market center, the lower the transaction cost, which is conducive to the development of business operation and reflects the market competitive advantage of cooperatives. Compared with Guangyuan, only Bazhong' cooperatives play a more significant role in promoting the income increase of members. Through careful analysis, it can be found that although there is a certain gap between the economic development level between Bazhong and Guangyuan(the GDP of two areas were respectively 50.13 billion and 60.54 billion in 2015), the former has a more relaxed policy environment in supporting and guiding the development of cooperatives and poverty alleviation. For instance, according to Bazhong Agriculture Bureau, statistics show that in 2015, cooperatives received loans of 8.81 million yuan, an increase of $179.7 \%$ over the previous year. 5 cooperatives received financial support funds, and the total support funds reached 2.4 million. Therefore, policy support plays an important role in promoting income increase of cooperatives members.

\section{Conclusions and policy recommendations}

\subsection{Conclusion}

Based on the perspective of income increase of cooperative members, this paper uses the micro survey data of 33 cooperatives and 394 members in QinlingBashan Mountainous Regions in Sichuan Province, to examine the poverty reduction effects of cooperatives and empirically analyze the factors influencing the poverty reduction effects of cooperatives by the orderly probit model. The results show that the income increase of most members is obvious, which is conducive to the in-depth development of local poverty alleviation. Besides, 9 variables play a significant role in promoting the income increase of members, which are health status, education level, number of labor, proportion of agricultural income, income satisfaction, cooperatives with county demonstration level, "Three Products and 
One Standard" certification, profit returned by stock/volume, member's right to speak. Compared with Guangyuan, the income increase of members in Bazhong is more significant. However, the poor families and the distance from the market significantly inhibit the income increase of members, which means the cooperatives also face the challenges in poverty reduction.

\subsection{Policy recommendations}

Cultivating and expanding cooperatives. Taking the establishment of demonstration cooperatives as an opportunity, we should constantly optimize the governance structure of cooperatives, improve the institutional construction of decision-making mechanism, distribution mechanism and supervision mechanism, and accelerate the standardized development of cooperatives. Taking the certification of "Three Products and One Standard" as an important step, we are supposed to take the initiative to make the cooperative bigger and stronger, effectively improving the sense of gain, happiness and security of the members. Only in this way can we consolidate the foundation of poverty reduction of the cooperative.

Strengthening the capacity of cooperatives to reduce poverty. We should promote cooperatives to establish special institutional arrangements to protect the interests of poor families, preventing the phenomenon of "elite capture" within them. Aiming at the members with a higher proportion of agricultural income, we should strengthen the training of advanced and applicable agricultural production technologies on the main business of cooperatives, strengthening their human capital, and making up for the deficiency of innate education level. At the same time, we should cultivate the awareness of ownership of the members and improve their subjective initiative, and they should be encouraged to actively participate in the daily production, operation, management and supervision of cooperatives, so as to form a close community of interests with cooperatives.

Improving the poverty reduction environment of cooperatives. We should step up efforts to improve rural infrastructure and public services, and then create a favorable external environment for the development of cooperatives, which can effectively reduce the transaction costs of cooperatives. We are supposed to continue to improve the new rural cooperative medical care system, striving to improve the health status of members and strengthen the quality of the labor. Besides, We should coordinate and integrate funds on cooperative cultivation and poverty alleviation, and resolve the capital bottleneck of poverty reduction faced by cooperatives in Qinling-Bashan Mountainous Regions in Sichuan Province.

\section{Acknowledgments}

Firstly, I am very grateful to my mentor for guiding me in the design, writing, and revision of my dissertation. Secondly, I thank my brothers and sisters in my mentor's team for helping me with the investigation.
Fund projects: (a) Soft Science Project from Science and Technology Department in Sichuan (2016ZR0240), (b) The key project from Sichuan Rural Development Research Center (CR1302), (c) Soft Science Project from the Ministry of Agriculture and Rural Affairs (201903), (d)Key Planning Project from Sichuan Province Social Science Federation (SC19A009).

\section{Reference}

[1] B. Wu, X. C. Xu, Pro-poor of farmers professional cooperatives and its mechanism [J]. Rural Economy, 2009 (03): 115-117.

[2] Z. Z. Bai, L. Li, Research on poverty alleviation by farmer Cooperatives in Wuling Mountain Area: A case study of Enshi Tujia and Miao Autonomous Prefecture [J]. Journal of South-Central University for Nationalities (Humanities and Social Sciences), 2017,37 (05) : 160-164.

[3] C. Zhang, Q. Gao, On the poverty alleviation effect of poor agricultural households by New Agricultural Management Entities [J]. Journal of Northwest A \& F University (Social Science Edition), 2017 (02): 73-79.

[4] K. Shao, Z. H. Yu, Functional mechanism, problems and policy suggestions of farmer cooperatives in promoting industrial precision poverty alleviation [J]. Rural Economy, 2017 (07): 120-123.

[5] W. H. Peng, Poverty reduction of farmer cooperatives: theoretical and empirical research [D]. Zhejiang University, 2018.

[6] J. W. Liu, The impact of farmer professional cooperatives on the income and Its' stability of poor farmers: A case study of Shandong and Guizhou Provinces [J]. China Rural Economy, 2017 (02): 4455.

[7] A. Sen. Poverty and famine [M]. Shanghai: Commercial Press, 2001.

[8] S. G. Wang, China's poverty alleviation performance and precision poverty alleviation [J]. Political Economics Review, 2020,11 (01): 130-148.

[9] L. Hu, Farmer professional cooperatives and farmers' income growth in poor areas-An empirical analysis based on Double Difference Method[J]. Finance and Economics Science, 2014 (12): 117-126.

[10] S. H. Zhang, Multidimensional poverty reduction effect analysis of cooperative economic organizations $[\mathrm{J}]$. Research on Financial and Economic Issues, 2019 (10): 122-129.

[11] X. J. Liao, R. Y. Ying, H. S. Deng, Z. G. Xu, Income effect and benefit distribution: A study on the effect of farmer cooperatives — An empirical study based on the differences in benefits of farmers in different roles of farmer professional cooperatives [J]. China Soft Science, 2016 (05) : 30-42. 
[12] R. Cai, "Cooperatives + Farmers" model: transaction cost savings and farmers' income increase effects: An empirical analysis based on a survey of apple farmers in Shandong Province [J]. China Rural Economy, 2011 (01): 58-65.

[13] X. C. Xu, B. Wu, L. Ying, Analysis on the influencing factors of financial performance of farmer professional cooperatives—Based on field investigation of 319 farmers professional cooperatives in Zhejiang Province [J]. Journal of Northwest A \& F University (Social Science Edition), 2013 ( 06): 20-26.

[14] J. H. Zhang, K. W. Feng, Y. W. Huang, Empirical research on farmer professional cooperatives' performance in increasing farmers' income [J]. China Rural Economy, 2012 (09): 4-12.

[15] Z. Wang, Analysis of the impact of cooperative governance mechanism on the income increase of members [J]. China Rural Economy, 2016 (06): 3950 .

[16] G. P. He, D. G. Liu, Product differentiation and income performance of farmer professional cooperative members $[\mathrm{J}]$. Journal of South China Agricultural University (Social Science Edition), 2016 (05): 45-54.

[17] Y. X. Liu, Research on farmer cooperatives' poverty alleviation model in continuous poverty areas [J]. Journal of Hunan University of Finance and Economics, 2016, 32 (06): 41-48.

[18] S. Z Huang, J. Lin, X. C. Xu, Empirical analysis on the governance mechanism and performance of farmer professional cooperatives $[\mathrm{J}]$. China Rural Economy, 2008 (03): 65-73.

[19] Q. Su, J. Chen, Analysis of the effect of farmer professional cooperatives on rice farmers' income increase: A case study of rice cooperatives in Hai'an County, Jiangsu Province [J]. Agricultural Technology and Economy, 2014 (08): 93-99.

[20] J. H. Zhang, K. W. Feng, Y. W. Huang, Empirical research on farmer cooperatives' performance in increasing farmers' income [J]. China Rural Economy, 2012 (09): 4-12.

[21] C. Zhang, Analysis of cooperative public service efficiency and its influencing factors - Based on a survey in Zhejiang Province [J]. Finance and Trade Research, 2016,27 (03): 63-71.

[22] X. C. Xu, Performance evaluation system of farmer professional cooperatives and its' verification $[\mathrm{J}]$. Agricultural Technology and Economy, 2009 (04): 11-19.

[23] T. Z. Wang, Bargaining power, viability, and economic performance of members of farmer cooperatives: an empirical analysis based on 381 questionnaires of farmer professional cooperatives [J]. China Rural Economy, 2016 (01): 53-68.
[24] F. Lou, S. G. Cheng, Q. Fan, Performance evaluation and influencing factors of farmer professional cooperatives $[\mathrm{J}]$. Journal of Beijing Institute of Technology (Social Science Edition), 2016 (02): 79-87. 